\title{
PHYTOCHEMICAL ANALYSIS ANDANTIBACTERIAL POTENTIAL OF LEAF EXTRACT OF BAUHINIA LINN.: AN ETHNOMEDICINAL PLANT
}

\author{
Javaria Afzal,1 Najeeb Ullah, ${ }^{2 *}$ Zahid Hussain,, ${ }^{3}$ Shah Rukh, ${ }^{2}$ MazharAyaz, ${ }^{4}$ Atif Akbar, ${ }^{5}$ Aqal Zaman ${ }^{1 *}$ \\ ${ }^{1}$ Institute of Pure and Applied Biology, Bahauddin Zakariya University, Multan-60800, Punjab, Pakistan. \\ ${ }^{2}$ Department of Biochemistry, Bahauddin Zakariya University, Multan-60800, Punjab, Pakistan. \\ ${ }^{3}$ Institute of Industrial Biotechnology, Government College University, Lahore, Punjab, Pakistan. \\ ${ }^{4}$ Faculty of Veterinary Sciences, Bahauddin Zakariya University, Multan-60800, Punjab, Pakistan. \\ ${ }_{5}^{5}$ epartment of Statistics, Bahauddin Zakariya University, Multan-60800, Punjab, Pakistan. \\ *Corresponding author email: aqalzaman@yahoo.com, najeebkhattak@bzu.edu.pk.
}

This is an open access article distributed under the Creative Commons Attribution License, which permits unrestricted use, distribution, and reproduction in any medium, provided the original work is properly cited.

\section{ARTICLE DETAILS \\ ABSTRACT}

\section{Article History:}

Received 6 July 2017

Accepted 10 October 2017

Available online 4 November 2017

Keywords:

drug resistance, leaf extract, zone of inhibition, microbial infections, peptidoglycan.
Various agents in medicinal plants are used in the same way as antibiotics in treatment of acquiring resistance in bacteria.The main objective of this study is to check out the bactericidal action of leaves of Bauhinia variegateLinnagainst medically important one Gram positive (Staphylococcus aureus) and three gramnegative bacterial strains (Proteus vulgaris, $S$. typhi and E. coli) by the method of disc diffusion. This method showed $24 \mathrm{~mm}$ maximum zone of inhibition against Staphylococcus aureus, $18.5 \mathrm{~mm}$ against Proteus vulgaris, $20 \mathrm{~mm}$ in Escherichia coli and $17.5 \mathrm{~mm}$ in Salmonella typhi.Zone of inhibition of extract was compared with standard antibiotic Cephalosporin. The phytochemical screening of ethanolic extract revealed many secondary metabolites existence,like flavonoids, terpenoids, tannins, steroids, glycosides and anthraquinones. Various plants are considered medicinal importance as having microbial activity due to containing many secondary metabolites. So, the development of research achievements in pharmacy is enhanced due to naturally occurring bioactive compounds of these plants.

\section{INTRODUCTION}

Antibacteria Theconsiderable originsfor the invention of new and competent drugs that utilizearound the world are traditional curative systems of herbal therapy[1]. The rate of acquiring drug resistance is rising dangerously in last decades is one of the possible reason of health problems. Drugs resistance have been caused some antibiotics to become almost obsolete and consequently new drugs must be desired [2, 3] Though a bulk of new antibiotics have been created bypharmacological industries in the previous three decades, yet microorganisms have developed resistance against these drugs. In general, the genetic capability of bacteria to spread and achieve resistance to drugs, may be appropriate as therapeutic agents [4]. Compounds within the herbal plants have been analyzed by numerous studies are effective antibiotics [5].The considerable and challengingmission for medicinal chemistswill consequently the exploring for new antimicrobial agents.

The important resources of natural antimicrobial compounds have considered as a large number of medicinal plants [6]. A vast untappedfountain for medicines areantimicrobials and antibacterial (plant based)and hence have colossal therapeutic potential. Therefore, curiosity on antimicrobial activityexhibitingin higher plant extracts has increased recent years [7-9]. Synthetic drugs are associated with many side effects, while antimicrobials drugs that found in plants have ability to reduce these adverse effects as well as improve treatment of these infectious disorders [10]. In pathogenic organisms, increased expression of multi drug resistance is due to indiscriminate use of antibiotics [11]. The synthetic antibiotics not only have high cost, but also have adverse side effectssuch as, allergic reactions, hypersensitivity immunosuppression etc, and in treating these infectious diseases are major burning global issues [12]. Although the commercial antibiotics had been invented by pharmacological industries time to time in considerable large number but pathogenic microorganism acquired resistance against these drugs at high rate and ultimately lead toward the situation of multi drug resistant in microorganism [13]. Diarrhea and septicemias are caused by Escherichia coliand it can also infect the gall bladder, surgical wounds, meninges, skin lesions, and the lungs especially in debilitate and immunodeficient patients. Urinary tract infections andwound infections are caused byProteus spp.in both the old and young men by following cystoscopy, and in ulcers pressure sores type disorders they are secondary invader [14] The hospital acquired infections are majorly caused by one of the class of gram positive round shaped bacteria that are Streptococcus aureus [15]. The surgical site infection and lower respiratory tract infections are primarily caused by it, pneumonia and myocardial infarctions are also caused by it [16]. The emerging resistant against antimicrobial drugs of especially Penicillin ( $\beta$ lactams) in S.aureus resulted in difficult to treat its infections [15]. Salmonella species is the source of salmonellosis disease [17]. The symptoms likeacute onset of fever,diarrhea, abdominal pain, nausea and sometimes vomiting are the clinical sources of human salmonellosis.Salmonellosis disease is most commonly associated in animals especially in swine and poultry [18]

In national health care programmers traditional/herbalremedies are majorityrecommends, boosts, and promotes by World Health Organization (WHO) because these drugs aresafe, easily available at low cost, and people have faith in them [19]. Bauhinia variegata Linn (Leguminosae) has been selected in order to augment the range of naturallyoccurringantibacterial agents. Bauhinia variegata, is the scientific name of Kachnar, is medium and of short duration tree found in India, China,Pakistan, and Nepal [20].For their medicinal properties, its bark, roots, seed, flowers are mainly used. The cooling, acrid, constipating,anthelmintic, depurative, and anti-inflammatory are the medicinal properties of the roots and barks [21]. They are useful in treating certain diseases such as diarrhea,skin disease, dysentery, leprosy,wound, intestinal worms, ulcers,cough, tumors and antidiabetic $[22,23]$. In folklore medicine, various diseases like inflammation is easily managed by the use of this plant [24]. In present study, Proteus vulgaris, Escherichia coli, Salmonellatyphi and Streptococcus aureus are taken as tested strains to check the antibacterial activity of plant extract Bauhinia variegata.

\section{MATERIAL AND METHOD}

\subsection{Plant collection and authentication}


Sample leaves were collected in month of June from Emerson College Bosan Road, Multan. The shape of different parts of plant (i.e) apex, margin, leaves base etc was examined morphologically etcby taxonomic experts from Department of Botany, Institute of Pure and Applied Biology, Bahauddin Zakariya University, Multan.

\subsection{Plant extract preparation}

Leaves were washed with tap water and placed under shaded area for drying. These were collected as they became crispy and subjected to grind to obtain a fine powder. This was, then, stored in polythene bag to use in further processes. For extraction purpose 300gm of powdered leaves socked in ethanol-distill water (70-30\%,v/v). Sample solution was tightly closed with lid to avoid evaporation of ethanol and well shook to homogenize all mixture by placing it at room temperature. During this mixture was occasionally shaken by hand. After 7-15 days socking process vegetative debris was passed through Whattman filter paper. To get crude extract solvent was evaporated with rotary evaporator under reduced pressure. Hence a thick sticky concentrated paste was collected in bottle jar which was kept at $4^{\circ} \mathrm{C}$ until tested or utilized.

\subsection{Antimicrobial assay}

Bactericidal action of extracts of plants was examined by using disc diffusion method [25,26]. Briefly, nutrient agar and MacCONKEY agar are used media to culture the bacteria. Sterilized cotton swab dipped into freshly prepared inoculums and streak three times at $60^{\circ}$ by opening the lid of agar plates against flame in a semi- confluent lawn. Sterile paper discs $(6 \mathrm{~mm})$ (Himedia) saturated withextracts $(20 \mu \mathrm{L})$ prepared in DMSO (having different concentrations) were aseptically placed on the upper layer of the inoculated nutrient agar and MacCONKEY agar surfaces, and plates were incubated at $37^{\circ} \mathrm{C}$ for 24 hour. Inhibition zones were appeared around the discs after 20-hour incubation which was recorded by zone reader in $\mathrm{mm}$. Results were compared with standard antibiotic Cephalosporin. $20 \mu \mathrm{L}$ DMSO in each discwas taken as a negative control. Results are described as mean \pm standard deviation by performingAntimicrobial assay in triplicates.

\subsection{Phytochemical screening}

To identify the chemical constituents using standard method of Harborne and Kokate, stock solution of leaves of Bauhinia variegata was subjected with various chemical tests

\section{RESULTS AND DISCUSSION}

To evaluate the antibacterial activity of ethanolicleaf extract Bauhinia variegata, disc diffusion assay was chosen. Disc diffusion assay is more appropriate way to know the susceptibility of bacteria against a tested drug/ sample.

Antimicrobial assay determined that leaf extract of $B$. variegata is more productive against Gram (+ve) bacteria in comparison to Gram (-ve) bacteria. Maximum zone of inhibition recorded forS. aureus was $25 \mathrm{~mm}$ at $0.8 \mathrm{mg} / \mathrm{mland}$ minimum zone of inhibition was $17 \mathrm{~mm}$ at and $0.7 \mathrm{mg} / \mathrm{ml}$ respectively illustrated in Figure. 1. Maximum zone of inhibition recorded for S.typhi was $17.5 \mathrm{~mm}$ at 0.9 and $0.7 \mathrm{mg} / \mathrm{ml}$ and $14.5 \mathrm{~mm}$ as minimum at $0.8 \mathrm{mg} / \mathrm{ml}$. In case of Proteus vulgaris maximum zone was $18.5 \mathrm{~mm}$ at concentration of $0.8 \mathrm{mg} / \mathrm{ml}$ and smaller inhibitory zone was $14 \mathrm{~mm}$ at $0.6 \mathrm{mg} / \mathrm{ml}$. Escherichia coli was inhibited by $20 \mathrm{~mm}$ zone of inhibition at $0.9 \mathrm{mg} / \mathrm{ml}$ and minimum zone of inhibition $10.5 \mathrm{~mm}$ was found at $0.6 \mathrm{mg} / \mathrm{ml}$ (Table. 1). Our results depicted that considerable antibacterial activity against Gram(+ve) bacteria was examined in comparison to Gram $(-v e)$ bacteria. The possible reason for this might be the presence of outer impermeable membrane, presence of periplasmic space, thin peptidoglycan single layer and cell wall composition in Gram negative bacteria due to which less or narrow activity was observed. Antibacterial activity of $B$. variegata was compared with standard drug Cephalosporin; pure antibiotic. It would be interesting to note that resistance shown by bacterial strains was remained independent to concentration of leaf extract. It means at some specific concentration more zone of inhibition was obtained as compared to its maximum concentration. Such irregular pattern was appeared in all bacterial strains except E. coli. E. coli only followed the traditional trend to some extend that increase in diameter of zone of inhibition with the increase of concentration of extract.

Extraction of plants can be carried out by different solvents like ethanol, acetone, methanol etc or sometimes these solvents are mixed with water to increase the extraction power. According a research, 20-95\% ethanol/ water is recommended in extraction of herbal medicines [27]. In present studies for phytochemical analysis of $B$. variegata leaves $70 \%$ ethanol was mixed to $30 \%$ water to form ethanol extract. Leaf extraction of $B$. variegata revealed the occurrence of terpenoids, flavonoids, steroids glycosides, and anthraquinoneswhile phlobatannins andsaponins were not identified in tested plant sample (Table. 2). According to a reserche, alcoholic extract of $B$. variegata possessed alkaloids, oils and fats, glycosides, simple phenolics, tannins and saponins while terpenoids and flavonoids were absent [28]. This difference may depend on many factors such as geological source, soil condition, moisture content, drying method etc.

According to one more research degree of variability of antimicrobial activity is dependent on the presence of phytochemical constituents extracted by solvent [8]. Flavonoids aresynthesized in feedback of microbial infections by plants, and are hydroxylated phenolic metabolites [29]. Many plants contain nontoxic glycosides, phenolics were released by hydolyzing glycosides, which are lethal to microbial germs [30].antibacterial activity is also the property of terpenoids, exhibited by membrane integrity weakness and proton motive force dissipation [31]. Therefore, the presence of these phenolic compounds could justify the antibacterial activity observed in B. variegata.

Table 1: Representation of the antibacterial efficacy at different concentration of Bauhinia variegata's leaves extract

\begin{tabular}{|c|c|c|c|c|c|}
\hline $\begin{array}{l}\text { Microorga } \\
\text { nisms }\end{array}$ & $\begin{array}{l}\text { Bacte } \\
\text { rial } \\
\text { strai } \\
\text { ns }\end{array}$ & $\begin{array}{l}\text { Concentr } \\
\text { ation } \\
\mathrm{g} / \mathrm{ml}\end{array}$ & $\begin{array}{l}\begin{array}{l}\text { Ethan } \\
\text { olic } \\
\text { extrac } \\
\text { t } \\
\text { DZoI( } \\
\text { mm) }\end{array} \\
\end{array}$ & $\begin{array}{l}\text { Stand } \\
\text { ard }\end{array}$ & $\begin{array}{l}\text { Cont } \\
\text { rol }\end{array}$ \\
\hline \multirow{4}{*}{$\begin{array}{l}\text { Staphyloco } \\
\text { ccus aureus }\end{array}$} & \multirow[t]{4}{*}{$\mathrm{G}+\mathrm{ve}$} & 0.9 & 24 & \multirow[t]{4}{*}{39} & \multirow[t]{4}{*}{-} \\
\hline & & 0.8 & 25 & & \\
\hline & & 0.7 & 17 & & \\
\hline & & 0.6 & 22 & & \\
\hline \multirow{4}{*}{$\begin{array}{l}\text { Proteus } \\
\text { vulgaris }\end{array}$} & \multirow[t]{4}{*}{ G -ve } & 0.9 & 14.5 & \multirow[t]{4}{*}{37.5} & \multirow[t]{4}{*}{-} \\
\hline & & 0.8 & 18.5 & & \\
\hline & & 0.7 & 16 & & \\
\hline & & 0.6 & 14 & & \\
\hline \multirow{4}{*}{$\begin{array}{l}\text { Escherichia } \\
\text { coli }\end{array}$} & \multirow[t]{4}{*}{ G-ve } & 0.9 & 20 & \multirow[t]{4}{*}{36.5} & \multirow[t]{4}{*}{-} \\
\hline & & 0.8 & 18.5 & & \\
\hline & & 0.7 & 15.5 & & \\
\hline & & 0.6 & 10.5 & & \\
\hline \multirow{4}{*}{$\begin{array}{l}\text { Salmonella } \\
\text { typhi }\end{array}$} & \multirow[t]{4}{*}{ G-ve } & 0.9 & 17.5 & \multirow[t]{4}{*}{25} & \multirow[t]{4}{*}{-} \\
\hline & & 0.8 & 14.5 & & \\
\hline & & 0.7 & 17.5 & & \\
\hline & & 0.6 & 17 & & \\
\hline
\end{tabular}

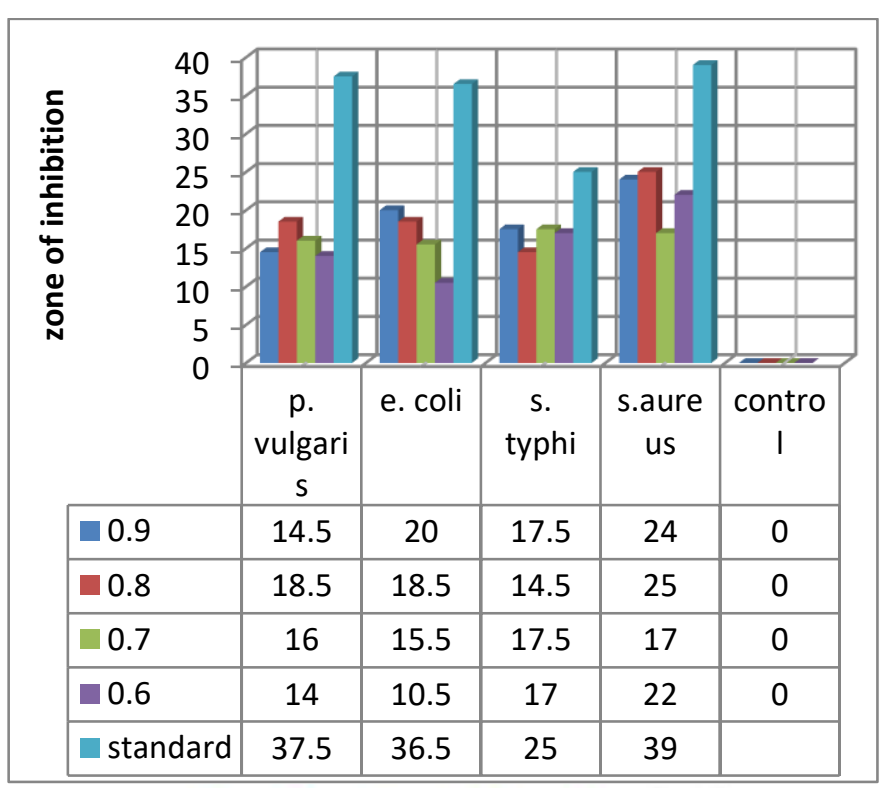

=0.9 $0.8=0.7=0.6$ = 0.8 standard

Figure 1: Graphical illustration is given to represent antibacterial activities by different strains of bacteria

Table 2: Phytochemical study of Bauhinia variegata's leaves extract 


\begin{tabular}{|l|l|}
\hline Phytochemical constituents & Alcoholic leaves \\
\hline Glycosides & Present \\
\hline Terpenoids & Present \\
\hline Flavonoids & Present \\
\hline Steroids & Present \\
\hline Phlobatannins & Absent \\
\hline Saponins & Present \\
\hline Tannins & Present \\
\hline Anthraquinones & Present \\
\hline
\end{tabular}

\section{CONCLUSION}

Bauhinia variegata and other herbal medicines would be a substitute of antibiotic which are becoming nonfunctional now a day with the emergence of resistance in pathogenic bacteria. This study needs further elaboration by applying it on animal models/ specimens directly to demonstrate the effects of Bauhinia variegata.

\section{REFRENCES}

[1] Okpekon, T., Yolou, S., Gleye, C., Roblot, F., Loiseau, P., Bories, C. 2004. Antiparasitic activities of medicinal plants used in Ivory Coast. Journal of ethnopharmacology, 90, 91-7.

[2] Farnsworth, N.R. 1993. Ethnopharmacology and future drug development: the North American experience. Journal of ethnopharmacology, 38, 137-43.

[3] Houghton, P.J. 1995. The role of plants in traditional medicine and current therapy. The Journal of Alternative and Complementary Medicine, 1, 131-43.

[4] Towers, G., Lopez, A., Hudson, J. 2001. Antiviral and antimicrobial activities of medicinal plants. Journal of Ethno-pharmacology, 77, 189-96.

[5] Basile, A., Sorbo, S., Giordano, S., Ricciardi, L., Ferrara, S., Montesano, D., 2000. Antibacterial and allelopathic activity of extract from Castanea sativa leaves. Fitoterapia, 71, S110-S6

[6] Mahady, G. 2005. Medicinal plants for the prevention and treatment of bacterial infections. Current pharmaceutical design, 11, 2405-27.

[7] Bagchi, A. 2000. Alternative medicine--old wine in a new bottle. Journal of the Indian Medical Association, 98, 332-3.

[8] Mishra, A.K., Mishra, A., Bhargava, A., Pandey,. AK. 2008. Antimicrobial activity of essential oils from the leaves of Cinnamomum spp. National Academy Science Letters, 31, 341-5.

[9] Maurya, A., Chauhan, P., Mishra, A., Pandey, A.K. 2012. Surface functionalization of $\mathrm{TiO} 2$ with plant extracts and their combined antimicrobial activities against E. faecalis and E. coli. Journal of Research Updates in Polymer Science, 1, 43.

[10] Iwu, M., Duncan, A.R., Okunji, C.O. 1999. New antimicrobials of plant origin. Perspectives on new crops and new uses ASHS Press, Alexandria, 457-62.

[11] Karaman, I., Şahin, F., Güllüce, M., Öğütçü, H., Şengül, M., Adıgüzel, A. 2003. Antimicrobial activity of aqueous and methanol extracts of Juniperus oxycedrus L. Journal of ethnopharmacology, 85, 231-5.

[12] Schinor, E.C., Salvador, M.J., Ito, I.Y., Dias, D.A. 2007. Evaluation of the antimicrobial activity of crude extracts and isolated constituents from Chresta scapigera. Brazilian Journal of Microbiology, 38,145-9.

[13] Niño, J., Narváez, D.M., Mosquera, O.M., Correa, Y.M. 2006. Antibacterial, antifungal and cytotoxic activities of eight Asteraceae and two Rubiaceae plants from Colombian biodiversity. Brazilian Journal of Microbiology, 37, 566-70.
[14] Rice-Evans C. 2004. Flavonoids and isoflavones: absorption, metabolism, and bioactivity. Free Radical Biology and Medicine, 36, 827 8.

[15] Klein, W.L. 2006. Synaptic targeting by A $\beta$ oligomers (ADDLS) as a basis for memory loss in early Alzheimer's disease. Alzheimer's and Dementia, 2, 43-55.

[16] Richards, J.B., Zhang, L., Mitchell, S.H., Wit, H. 1991. Delay or probability discounting in a model of impulsive behavior: effect of alcohol. Journal of the experimental analysis of behavior, 71, 121-43.

[17] WH0.2002. Traditional medicine-growing needs and potential. WHO policy perspectives on medicine, No. 2. World Health Organization, Genève.

[18] Hardt, W.D., Chen, L.M., Schuebel, K.E., Bustelo, X.R., Galan, J.E. 1998 S. typhimurium encodes an activator of Rho GTPases that induces membrane ruffling and nuclear responses in host cells. Cell, 93, 815-26.

[19] Pandey, A., Tripathi, S. 2014. Concept of standardization, extraction and pre phytochemical screening strategies for herbal drug. Journal of Pharmacognosy and Phytochemistry, 2.

[20] Kumari, M. 2012. Evaluation of ethanolic extracts of In vitro grown Bauhinia variegate L. for antibacterial activities. International Journal of Pharma and Bio Sciences, 3, 43-50.

[21] Rastogi, R.P., Mehrotra, B., Pastogi, R.P. 1995. Compendium of Indian medicinal plants: Central Drug Research Institute; Publications \& Information Directorate.

[22] Yadava,. R, Reddy, V.M.S. 2003. Anti-inflammatory activity of a novel flavonol glycoside from the Bauhinia variegata Linn. Natural product research,17, 165-9.

[23] Azevedo, C.R., Maciel, F.M., Silva, L., Ferreira, A., Da Cunha, M., Machado, 0. 2006. Isolation and intracellular localization of insulin-like proteins from leaves of Bauhinia variegata. Brazilian journal of medical and biological research, 39, 1435-44.

[24] Cechinel Filho, V. 2009. Chemical composition and biological potential of plants from the genus Bauhinia. Phytother Res, 23, 1347-54.

[25] Alzoreky, N., Nakahara, K. 2003. Antibacterial activity of extracts from some edible plants commonly consumed in Asia. International journal of food microbiology, 80, 223-30.

[26] Bauer, A., Kirby, W., Sherris, J.C., Turck, M. 1966. Antibiotic susceptibility testing by a standardized single disk method. American journal of clinical pathology, 45, 493.

[27] Wendakoon, C., Calderon, P., Gagnon, D. 2012. Evaluation of selected medicinal plants extracted in different ethanol concentrations for antibacterial activity against human pathogens. Journal of Medicinally Active Plants, 1, 4

[28] Dhale, D. 2011. Phytochemical screening and antimicrobial activity of Bauhinia variegata Linn. Journal of Ecobiotechnology, 3.

[29] Dixon, R., Dey, P., Lamb, C. 1983. Phytoalexins: enzymology and molecular biology. Advances in enzymology and related areas of molecular biology, 55 .

[30] Efuwape, A.O. 2001. Antibacterial properties of some Nigerian Spices. Molecular Biology Research Communications, 13,183-8.

[31] Sikkema, J., De Bont, J., Poolman, B. 1994. Interactions of cyclic hydrocarbons with biological membranes. Journal of Biological Chemistry, 269 (11), 8022-8. 